\title{
The Complexity of Business-Government Relations in Ghana: Implication for State-Market-Society Nexus
}

\author{
Eugene Danso \\ Department of Political Science, Brock University \\ 1812 Sir Isaac Brock Way, St. Catharines, Ontario, Canada \\ E-mail: ed17pa@brocku.ca
}

Received: Sep. 23, 2020 Accepted: Oct. 26, 2020 Online published: Nov. 18, 2020

doi:10.5296/jpag.v10i4.17732ＵRL: https://doi.org/10.5296/jpag.v10i4.17732

\begin{abstract}
The complexity of business-government relations in the globalized economy cannot be underestimated. This is the product of the cross-cutting effects of a long-term policy shift heightened by globalization, coupled with privatization. Central to this, is the emergence of ideologies within the contours of the state-market-society landscape. Ghana's privatization experience is typical of this major ideological approach to business-government relations. As a qualitative study, this paper adopts unobtrusive content analysis of an empirical study of the privatization of Ashanti Goldfields Company (AGC). This paper argues that Ghana's adoption of privatization policy has yielded undesirable policy outcomes due to the complexities of the divestiture process which had adverse effect on the state-market-society nexus.
\end{abstract}

Keywords: complexities, state-owned enterprises, business-government relations, privatization

\section{Introduction}

Developing countries, mostly in sub-Saharan Africa, embraced the neo-liberal principle of privatization by the early 1980s as a condition under the World Bank/IMF SAP (Nellis, 2008; Kikeri \& Nellis, 2004). Ghana is not an exception to this. Ghana's drive towards privatization was initiated by the PNDC $^{1}$ government with the adoption of SAP. The protection of strategic industries is crucial for every government in ensuring sustainable development, and more so, in building the trust and confidence of the citizenry. However, Ghana's adoption of privatization has yielded undesirable policy outcomes due to the complexities of the

\footnotetext{
1 The Provisional National Defence Council (PNDC) was a military government chaired by Flt. Left. Jerry John Rawlings that ruled Ghana from 1981 to 1992 when the country returned to constitutional rule.
} 
divestiture process. In 2003, the World Bank (the chief advocate of privatization in Ghana) acknowledged that Ghana has not benefited from mining activities in terms of revenue, employment, infrastructure development and environmental sustainability and urged Ghana's leaders to take steps to reverse the trend but nothing happened (Adusei, 2016). Using very diplomatic words the World Bank wrote that, it is unclear what gold mining true benefits are to Ghana (Adusei, 2016). Large scale mining by foreign companies has high import content and produces only modest amounts of net foreign exchange for Ghana after accounting for all its outflows (Adusei, 2016). Similarly, its corporate tax payments are low due to various fiscal incentives necessary to attract and retain foreign investors (Adusei, 2016). Employment creation is also modest given the highly capital-intensive nature of modern surface mining techniques (Adusei, 2016). Local communities affected by large scale mining have seen little benefits to date in the form of improved infrastructure or services provision because much of the rents from mining are used to finance recurrent, not capital expenditure (Adusei, 2016). A broader cost-benefit analysis of large-scale mining that factors in social and environmental costs and includes consultations with the affected communities needs to be undertaken before granting future production licenses (Adusei, 2016). Therefore, this study seeks to draw lessons from the privatization of Ashanti Goldfields Company Limited in Ghana and its policy implications.

\section{Methodology}

This paper adopts qualitative method of study. A qualitative case study research aims to make sense of a phenomenon in its context without a direct influence or disturbance on variables of interest (Bryman \& Bell, 2011; Tewksbury, 2009). A qualitative approach is more appropriate for research that aims at investigating the rationale and providing a systematic empirical inquiry into the meaning of an event or case (Atkins \& Wallace, 2012; Cresswell, 2009; Osuala, 2007). This is in stark contrast to other research approaches, particularly quantitative research that largely focuses on the cause and effect (Berg \& Howard, 2012; Kothari, 2004). This makes qualitative method the most suitable approach for this study since the primary focus of this study is not only to establish an outcome but rather provide an account of the terms of the stability agreement between Ashanti Goldfields Company Limited and AngloGold.

\subsection{Data Collection}

The study employed both primary and secondary sources of data. Primary sources include; government documents, policy reports and online newspaper publications. Secondary sources cover; academic and grey literature. In the process of data collection and information gathering, one major limitation this study encountered was data availability. This study draws on available pieces of information and data sourced from scattered and a relatively small number of materials and references. The available data appears disarranged. To present a systematic data, the researcher uniquely presents these scattered pieces of information into time frame and events to ensure coherence. 


\section{The Intellectual Debate on the State-Market-Society Nexus}

The ascendency of neoliberal economic perspectives has generated a significant debate about the role of the state in the marketplace. The shift towards neo-liberalism had implications for both the market and government structures. Neoliberalism entails systematic efforts to accommodate global interdependence resulting from economic globalization in trade, investment, and regulatory policies; the pursuit of fiscal balance and sustainability; helping adjust to changes resulting from globalization; and the expanded use of market incentives and mechanisms to the design of social programs and delivery of public services (Hale, 2018).

Essential features of neo-liberalism entail the rule of the market, privatization, deregulation, reduction in government spending, free trade and others. Neoliberalism ensures an open and competitive market system based on supply and demand. Global economic imperatives continue to dictate market forces. In the context of the privatization debate, the neoclassical perspectives translate into policy prescriptions geared towards a minimization in the size of the public sector, the reduction of government controls, the enhancement of competition, and a huge dependence on the market structures and price mechanism for the distribution of resources (Obadan, 2009; Handley, 2007). The push towards privatization has been contingent on the neoclassical hypothesis that private ownership of business, as compared to public ownership, results in greater efficiency and rapid economic growth and development (Obadan, 2009).

The intrinsic reality of the market, the very epoch of the market space tends to be in favour of the private sector, thereby creating an uneasy partnership within the state-market-society spectrum. The paradigm shift in ideologies, political cultures, market (economic and technological) conditions coupled with public expectations and other external demands has further led to uneasy partnership within government-business relations. In a democratic market economy, state intervention in the push towards economic growth is crucial in influencing public policy outcomes. The state exists to provide essential needs for the enhancement of societal welfare. However, the withdrawal of the state in the provision of these basic utilities such as water, electricity, and medical supplies has diverse repercussions for the wellbeing of its citizens.

Despite the state stepping aside to allow the market forces to operate freely, there is still the issue of growing mutual dependence between businesses and governments. Here, there is the principle of reciprocity (Hale, 2018). Business owners often seek protection against negative externalities to their business transactions. On the other side, governments depend on these businesses for financial support and the creation of avenues of economic opportunities (Hale, 2018). The repercussion of this is that the 'umbilical cord' that provides the network of state control over market forces in the best interest of the consumer is gradually losing grounds, since states have now assumed the role of a facilitator of markets. There is still the mind-puzzling question about how far the state should go in engaging with the market. However, with the growing expansion of privatization efforts by private organizations coupled with the complexity of government functions, raises several questions about the legitimate role of the state in the political and economic market place, especially in 
promoting economic development; correcting market failures; promoting a government ideology and exercising policy control over strategic industries.

\section{Privatization of State-Owned Enterprises in Ghana}

The emergence of state-owned enterprises in Ghana can be traced to the colonial period, where the colonial government established public utilities to provide essential services in the urban centres (Appiah-Kubi, 2001; Potter, 2015). The prices of utilities were high, which made it difficult for most Ghanaians to afford. However, this system was regarded as a 'natural monopoly' which resulted in market failures, hence the need for state intervention. Minimal growth was achieved in the industrial sector during the colonial period (Appiah-Kubi, 2001). The shift towards a more state-oriented economy was engineered by Ghana's first president Kwame Nkrumah. During the 1950s under his regime, strategic industries such as the Cocoa Purchasing Company (CPC), Bank of Ghana, Agricultural Development Corporation as well as the Ghana Commercial Bank were established (Appiah-Kubi, 2001). This was to give the market a more commercial outlook. The focus of Nkrumah's government was about the welfare of the citizenry. His government geared towards the institutionalization of welfare policies. Subsequent government made some efforts in creating additional state-owned enterprises.

The National Liberation Council (NLC) led by Lt. General J. A. Ankrah, attempted to shift the market economy towards privatization but received fierce resistance from the public (Appiah-Kubi, 2001). The public outburst was enough to rescind the decision of the NLC government. Busia's government that took over from the NLC made some frantic effort towards state-oriented market economy with the establishment of SOEs such as the Export Promotion Company, the Bast Fibres, the Cotton and Grains Development Boards. The Acheampong's government that succeeded Busia, saw the nationalization of foreign owned companies such as Loyal Group of Companies, and others (Appiah-Kubi, 2001). "There was the confiscation of the assets of privately-owned companies for committing economic crimes against the state" (Danso, 1992, p.342). He also established industries such as the Meat Marketing Board and others. Under a series of participation decrees, the state became a major shareholder of multinational corporations operating in Ghana (Appiah-Kubi, 2001). His government played a commandeering role of the market structure. As Danso (1992, p.342) clearly notes, "the proliferation of SOEs did not come with commensurate mechanisms to ensure their efficient performance other than creating new layers of bureaucracies to exercise general supervision". Despite the reorganization of about eighteen confiscated companies under the Supreme Military Council (SMC) and Armed Forces Revolutionary Council (AFRC) era, the financial losses of the SOEs persisted (Gyimah-Boadi, 1990).

Consequently, the shift towards previsualization was heightened became more intense within Ghana's political landscape during period of global economic meltdown (Nellis, 1986; Obadan, 2009). This is because various attempts at reform had resulted into budget deficits and accrued financial loss (Appiah-Kubi, 2001). However, intergovernmental organizations emerged during the 1970s and 1980s embracing the meteoric rise of neoliberal principles of privatization (Obadan, 2009). Ntiri (2010) identifies privatization as comprising of; sale of 
assets, sale of shares, management contracts, joint venture, lease and liquidation. Privatization was part of the economic policy prescriptions under the Washington Consensus, which composed of the IMF/World Bank and the United States Department of Treasury. It constituted reform packages for developing countries facing the economic downturn. "Privatization in developing nations emerged as a policy issue amidst the debt crises and worsening fiscal budget during the seventies and early eighties" (Appiah-Kubi, 2001, p.197). Privatization was introduced in sub-Saharan Africa as a condition under the Structural Adjustment Program (SAP) of the two Bretton Woods institutions, the International Monetary Fund (IMF) and the World Bank (Boafo-Arthur, 1999; Appiah-Kubi, 2001). "Privatization in sub-Saharan Africa was intended to minimize distortions associated with resource allocations, reduce social and economic inequalities, reduce budget deficits, reverse brain drain, create new employment opportunities, improve the efficiency of physical infrastructure, and improve the balance of payments" (Danso, 2019, p.186).

The Structural Adjustment Program (SAP) was a comprehensive economic initiative consisting of loans provided by the IMF/World Bank to countries that experienced economic crises (Boafo-Arthur, 1999; Gyimah-Boadi, 1990). However, there were some conditionalities or austerity measures that countries needed to fulfill as a requirement under the SAP (Asante, 1987; Danso, 2019). These conditionalities range from trade liberalization and fiscal discipline. Some of which are; deregulating banking sectors, cutting expenditures, removing trade barriers, privatization or divestiture of all or part of state-owned enterprises (privatizing natural resources and government industries), devaluating currencies, strictly adhering to balance deficits and building up export economies (Addo, 2014). With the wave of democratization spreading across Africa in the 1990s, political liberalization in the 1990s created the avenue for governments to shift the focus from public to private oriented interest (Appiah-Kubi, 2001; Gyimah-Boadi, 1991). Privatization served as a persuasive tool for mobilizing political support since it was regarded as a means for rent allocation (Appiah-Kubi, 2001; Tweneboah, 1999). Ghana presents a typical case study where the country has witnessed a political and socio-economic trajectory of a privatization program.

However, by the early 1980s, when the economic crisis had reached its summit, Ghana under the PNDC regime, signed onto the infamous Structural Adjustment Program (SAP) of the World Bank and the IMF (Kusi, 1991; Boafo-Arthur, 1999). Underperforming SOEs constituted a huge backlog on government financial expenditures (Boafo-Arthur, 1999; Kusi, 1991; Tangri, 1991). Danso (1992) observes that by the early 1980 era, there was a massive SOE reliance on government financial assistance. "By 1983, accrued domestic and external debts of non-financial Public enterprises was about $19.3 \%$ and $32.3 \%$ of the total outstanding Ghanaian external and domestic debts respectively" (Appiah-Kubi, 2001, p. 203). Apart from operating deficits of "0.2-3.4 percent of GDP, several SOEs relied on government subsidies to the tune of $9 \%$ of government financial expenditure" (Kusi 1991, p. 188-89). There was an increase of government subventions to SOEs from "1.1 billion Ghanaian cedis in 1982 (10\% of government expenditure) to 7.35 billion cedis in 1986 (8\% of government expenditure)" (Danso, 1992, p.343). Outstanding Ghana government loans to SOEs increased from "500 million cedis in 1980 to 1.9 billion cedis in 1985" (Danso, 1992, p.343). "A cross debt study 
of some 18 SOEs undertaken in 1987 showed that by June 30, 1986, 18 enterprises were indebted to the government to the tune of 40 billion cedis, while they owed 5.2 billion cedis among themselves" (Danso, 1992, p.343). Compounding these problems was the fact that the SOEs were unable to meet their tax obligations, pay social security on behalf of their employees or service government guaranteed loans on which virtually no interest was being paid (Danso, 1992, p.343).

Ghana's drive towards privatization of strategic SOEs was a strict adherence of the conditionalities of the IMF/World Bank Structural Adjustment Program (SAP) (Danso, 2019; Abebrese, 2011; Osei, 2011; PRS, 2004). Tangri (1991) observes that the primary objective for the PNDC government's adoption of divestiture was that its political survival was contingent upon initiating such reforms as demanded by external agencies. Danso (1992, p. 344) identified some major factors inhibiting SOE performance. These were; constraints attributable to inadequacies, inconsistencies, and unclarity of government policies, excessive political interference in the operations of SOEs and stifling of entrepreneurship arising from excessive governmental regulations or controls. The debilitating challenges facing the SOEs was symptomatic of a major economic crisis that has crippled the political marketplace.

The PNDC government subsequently introduced SOE reforms in the buildup to privatization (Handley, 2007). The attention of the Ghanaian market was gradually shifting towards the private sector. This was not a viable option that many in government were ideologically passionate about (Handley, 2007). The repercussion is that the state is now beginning to lose the grip of the marketplace. The SOE reforms entailed two main components: the divestiture components: divestiture, which entails the transfer of ownership of assets or management of enterprises to the private sector; and liberalization, which implied exposing enterprises to more competition (Appiah-Kubi, 2001). The divestiture program was introduced as a flagship policy of the privatization process (DIC, 1999; Gyimah-Boadi, 1990). The program sought to reduce the size of the public sector, generate revenue, and improve the performance of enterprises by mobilizing private sector management and capital (Handley, 2007). In 1987, the PNDC government as part of its Economic Recovery Program (ERP) created the Divestiture Implementation Committee (DIC) to the execution of all government policies with respect to the Divestiture program (Appiah-Kubi, 2001; Danso, 1992; Potter, 2015; Haruna, 2003). Primary functions of the DIC are clearly stipulated in the Divestiture of State Interest (Implementation) Law 1993 (PNDC Law 326);

a) to plan, monitor, coordinate and evaluate all divestitures;

b) to arrange for the effective communication of government policies and objectives for any divestiture;

c) to develop criteria for the selection of enterprises to be divested and assume responsibility for preparing such enterprises for divestiture;

d) to make appropriate consultations for successful processing of all divestiture programs; and 
e) to ensure consistency in procedures for divestiture, in particular with regard to valuation, invitation for bids, negotiation of sales and settlement of account.

During the initial stages of the privatization process, the DIC was an internal division under SEC. However, as their mandate expanded and became more complex, the DIC became an autonomous body in 1993 under PNDC Law 326 (Appiah-Kubi, 2001). The DIC comprise of ministers of state, institutional and private sector representatives and trades union. The Executive Secretary heads the Secretariat who oversee the running of the day-to-day administration of the DIC (Appiah-Kubi, 2001; Potter, 2015; WINE, 1999). The committee members of DIC meet regularly to consider, among other things, specific transactions negotiated by the Secretariat, submitting, as applicable, recommendations to the President's Office for approval (Appiah-Kubi, 2001; WINE, 1999). DIC is assisted by specialized sub-committees on mining and cocoa and coffee plantations (WINE, 1999). The DIC implemented various modes of the divestiture which includes the following (Danso, 1992, p.207);

a) trade sale to a private sector investor or consortium of the enterprise's assets;

b) creation of joint venture companies between the state and the private sector investor with the state as minority shareholder while management control goes to the private sector;

c) total liquidation of assets to private investors with existing liabilities, not passed on to investors;

d) leasing of plant and equipment, where the investors undertake the necessary investment to upgrade the assets and manage them for an agreed period with an option to acquire the assets within the lease term;

e) sale of shares in enterprises, where there are already shareholders other than the government.

By 1999 about 70\% SOEs had been privatized (Handley, 2007). The process of privatization had an impact on state-owned enterprises including strategic sectors such as the manufacturing, food, utilities, and others. The wave of privatization took various forms including an outright sale, partnership, deregulation, and contracting (Haruna, 2003; Danso, 2001; Gyimah-Boadi, 1990). For instance, "the Ghana Agro-Food Company Limited became a joint venture between Ghana and Industrie Bau Nord AG (Switzerland)" (Haruna, 2003, p.345). Most public corporations by December 1998 had been divested (Haruna, 2003). With the privatization of SOEs, the public concern was that it was weakening the role of the state and diverting such a role in favor of market forces, private interests, and business firms. The policy implementation of the program focused so much on public finance rationalization system, and less on sociopolitical aspects.

\section{Ashanti Goldfields Company (AGC) Divestiture}

The divestiture of Ashanti Goldfields Company (AGC) depicts the impact of neoliberal principles on the Ghanaian economy (Handley, 2007). The divestiture of AGC was a 
sequential process which started off under the PNDC/NDC ${ }^{2}$ era under Flt. Lft. Jerry John Rawlings in 1994 as a public listing, and subsequently a merger with a global firm in 2003, under liberal the New Patriotic Party (NPP) government under Former President John Agyekum Kufuor. Handley (2007) observes that the drive towards privatization of AGC under the two regimes was characterized by a set of conflicting pressures, which are; economic pressure to generate revenue from AGC that could relieve the state's position; political pressure from the international financial institutions to use privatization to secure the regimes policy credibility, and the close but shifting personal relationship between the country's President and the AGC Chief Executive Officer (CEO). The NPP government were inclined towards market liberalism. This informed their push towards privatization. "Since 1993, AGC contributed 12\% of all payments to the Internal Revenue Service" (Handley, 2007, p.4). The AGC was the largest employer outside of government. It came as no surprise that the AGC was a politically and economic target for privatization in Ghana. Handley (2007) observes that AGC was seeking to inject capital and re-invest in its technological and industrial base. The company was seeking to control the flow of capital and develop a global standard to withstand global competition.

In 1994, the Mineral's Commission and the Ministry of Finance, in agreement with the board of directors of AGC decided to sell off a portion of shares owned by government. Subsequently, the Divestiture Implementation Committee (DIC) proposed for the government to dispose part of shareholdings in the company. With the sale of government shareholdings of about " $20 \%$ and a further 5\% through the Ghana Stock Exchange, the company was able to expand its import and export earnings" (Handley, 2007, p.11). Gold production increased from "2440000 ounces in the mid-1980s to 770000 ounces in the early to mid-1990s" (Handley, 2007, p.11). AGC became the first African company to be listed on the New York Stock Exchange. In the process, the government reduced its holdings from $45 \%$ to $19.8 \%$ in return for an injection of capital. Previously the government of Ghana held veto power over policy decisions in the company. This was contingent on the majority of shares it held in the company. On the other hand, Lonmin company, one of the single largest shareholders now held $27.6 \%$ of shares. The government was able to acquire new technologies which made this feat possible (AngloGold Ashanti, 2005). Accordingly, parliament successfully passed the New Minerals and Mining Law and Companies Code and Securities law, consolidating and clarifying the leasehold arrangement between the company and government.

However, the privatization of AGC was met with internal dissatisfaction and public outburst, as concerns were raised about the sale of the strategic industry to foreign owners. Tension mounted on the government to provide justification for the sale. Both print and electronic media painted a gloomy picture of the agreement. It was described by many Ghanaians as a shady agreement, since it was done at the blind side of the public. As political tension arose, the government together with the board of directors of AGC decided to create preferential opportunities for locals to own shares in the company. There were publications in the media informing the public about the sale of shares. The government and AGC board of directors

\footnotetext{
${ }^{2}$ Upon Ghana's transition to multiparty democracy in 1992, the Provincial National Defence Council, a military group metamorphosed into a political party, National Democratic Congress (NDC).
} 
created an avenue for public sector employees to also own shares in the company. The government developed schemes to facilitate the purchase of shares by public sector employees. Handley (2007, p.12) observes that the "AGC set aside US\$ 1 million to purchase shares on behalf of workers". In 1994, the company witnessed its largest flotation, which was an indication of the PNDC government commitment to promoting a neoliberal reform.

Subsequently in the late 1990s, the AGC was met with an economic downturn which crippled the company's revenue base. This stems from the fact that there was a steep rise in the price of gold. The AGC initiated a hedging strategy to deal with gold price fluctuations in 1997. This was known as the hedging debacle. Hedging strategy was initiated by AGC in order to reduce the fluctuations associated with the international price. AGC hedging strategy had two objectives; To provide shareholder exposure to upward movement in the gold price and to ensure that company's ability to conduct business and its obligations are in no way jeopardized by downward fluctuations in the gold price (Handley, 2007). Adopting the hedging strategy really served the company well allowing it to maintain a high level of profitability despite a lackluster of gold price (Handley, 2007). In 1990, about 70 percent of AGC reserve position was hedged. "Two years later 46 percent of Ashanti reserve position were hedged" (Handley, 2007, p.14).

"However, it was hardly anticipated that the prices of gold will rise. Unfortunately, in late September and early October, the prices of gold steadily increased to US \$86 in just eleven trading days" (Handley, 2007, p.14). This placed the AGC in huge financial crisis. The company's liquidity problems were exacerbated with the failure to secure a loan from the government. Perhaps, the government is was constrained by the austerity measures in the SAP. The government is expected to seek approval from the IMF/World bank in the allocation of funds. It was projected that the company was unable to secure the needed financial assistance from major lending banks in the country. The loans on its own were not enough. Money was to be raised to resuscitate the company. The government ordered for the sale of strategic assets of the company. Hedging is a complex financial instrument and the Ghanaian business community was entirely lost. Rawlings failed to listen to financial advisors who tried to explain the mechanics of the crisis. Handley (2007) observes that the company was so reckless in the implementation of the hedging strategy. She argues that the company was over-exposed to the risk of an increase in gold prices.

Subsequently, a general election was held in 2000 which led to a successful change of government. Though several parties contested in the 2000 elections, it was a two-horse race between the New Patriotic Party (NPP) and the National Democracy Congress (NDC) (Hamid, 2016). Though it was won by the New Patriotic Party, it was a fiercely contested election (Frempong, 2017). As a liberal party, the NPP government championed the course of neoliberalism. The neoliberal economic reforms initiated by the PNDC/NDC government was in line with NPPs liberal ideology. The NPP faced a daunting task of reviving the AGC. In 2001, the Ghana Mining Commission recommended that the state should dispose off its golden share in the company. The hedging debacle had damaged the AGC's risk profile and this would also affect the company's drive in upgrading and expansion, and hence, its future profitability. The NPP government together with the board of directors of AGC reached a 
consensus that the company needs to raise a substantial level of capital. To achieve that, the government propose a possible partnership with a credible partner with an international reputation. Talks were initiated with a number of firms such as Randgold and AngloGold for a possible merger. Subsequently, the South African firm, AngloGold, emerged as the leading candidate. In March 2003, the government and AGC confirmed their discussions with AngloGold, which had the support of Lonmin Company which held $27.6 \%$ of shares (GhanaWeb, 2003). The government of Ghana declared support for AngloGold because of the company's operational experience in deep level mining as well as its capital endowment.

\subsection{Rationale for the Stability Agreement}

As projected in the stability agreement, the combined group will possess growth/upside potential with enhanced production and exploration and a land holding portfolio (GhanaWeb, 2003). AngloGold has over the years demonstrated enhanced development of deep level projects which will be beneficial for the growth of deep level underground mining at Obuasi (Obuasi Deeps), where empirical studies have been conducted on the mine's production rates, infrastructure options and operating and capital cost projections (GhanaWeb, 2003).

As part of the terms of contract, a team will be deployed to assess anticipated exploration expenditure of US\$44 million over the next five years (GhanaWeb, 2003). It is estimated that the total capital expenditure for Obuasi Deeps is projected to be US\$570 million in actual terms (GhanaWeb, 2003). The new group is expected to inject US\$ 110 million over a five-year period on infrastructure, equipment, environmental and planning systems for the Obuasi mine. It is anticipated that these policies will promote efficiency and reduce operational costs by US $\$ 20$ per once over the five years period (GhanaWeb, 2003). It is estimated that this merger will reduce financial costs, administrative and procurement costs. There will also be a consolidation of Geita Ownership. In reserves, AngloGold is expected to receive a $31 \%$ increase in reserve base, and a $27 \%$ increase on production level (GhanaWeb, 2003). With regards to operational strength, the combined group will have a portfolio for low-cost assets and different ore body types across the major gold producing regions (GhanaWeb, 2003). There will also be a well-diversified asset portfolio and underground production from a total of 24 operations distributed across eleven (11) countries in the major gold producing companies in the world (GhanaWeb, 2003).With this merger, liquidity is expected to increase especially in North America which represents some two thirds of AngloGold and Ashanti's combined share turnover (GhanaWeb, 2003). The proposal was therefore presented before the government of Ghana for consideration. The merger was contingent on government's approval and subject to regulations and undertakings. The government of Ghana then appointed a consortium of advisers led by Société Générale was inaugurated to assist the Government in its assessment and consideration of the proposed merger (GhanaWeb, 2003).

\subsection{Terms of Divestiture}

After a successful consultation and deliberations, the government of Ghana in 2004 declared the successful merger of Ashanti Goldfields Company with AngloGold under a Stability Agreement, with AngloGold holding majority shares of 33\%, Lonmin Company holding 
$27.6 \%$, the government of Ghana having $15 \%$ and the other $24.4 \%$ being held by private individuals. The combined group was established under the name AngloGold Ashanti Limited. According to the publication of the Ghana High Court order on Friday April 23, 2004, AngloGold will acquire the entire issue shared ordinary capital of Ashanti effective April 26, 2004 (AngloGold Ashanti, 2004, p.1). Under this agreement, each holder of Ashanti's ordinary shares and global depositary securities will be entitled to receive either 0.26 AngloGold share or 0.26 AngloGold American Depository share (GhanaWeb, 2003). The merger agreement values Ashanti's stock at $\$ 8.36$ each and amounts to aggregate consideration of $\$ 1.089$ billion (MarketWatch, 2003). This represents a premium of approximately $4 \%$ to the closing market price of Ashanti GDSs on the New York Stock Exchange on 1 August 2003, the last practicable trading day prior to this announcement, of US\$8.00 and, on the basis of closing prices for AngloGold ADSs and Ashanti GDSs on the New York Stock Exchange on 15 May 2003, the day prior to the announcements of discussions, of US\$30.63 and US\$7.10 respectively, a premium of 12\% (GhanaWeb, 2003). Based on the average closing prices of Ashanti GDSs and AngloGold ADSs on the New York Stock Exchange over the 30 trading days up to and including 15 May 2003 these terms represent a premium of $34 \%$ (GhanaWeb, 2003)

The terms of the agreement is to extend the term of the mining lease relating to the Obuasi mine until 2054 on terms existing prior to the business combination; to maintain for a period of 15 years, the royalties payable by Ashanti with respect to its mining operations in Ghana at a rate of $3 \%$ per annum of the total revenue from minerals obtained by Ashanti from such mining operations; to maintain the corporate tax rate for Ashanti and fix this rate for each of its subsidiaries in Ghana at $30 \%$ for a period of 15 years; that a sale of Ashanti or any of its subsidiaries' assets located in Ghana remain subject to the government's approval; to retain its special rights (Golden Share) under the provisions of the mining law pertaining to the control of a mining company, in respect of the Obuasi mine; (AngloGold Ashanti, 2005).

\section{Policy Implication}

Firstly, the absence of key monitoring and evaluation measures had adverse effects on the company's performance. The company in 2004, it operated six gold producing mines in four African countries with active exploration projects in seven African countries (Nikoi, 2015, p.602). The company's measured and indicated gold resource base reached 44 million ounces, dramatically increasing gold output from a low of $232000 \mathrm{oz} / \mathrm{year}$ in the 1980s to more than 1.6 million ounces per annum in 2002. With this resource base and rate of gold production, Ashanti Gold Fields was a major gold conglomerate (Nikoi, 2015, p.602). However, the government failed to look at the pros and cons of the terms of divestiture, especially with corporate tax and the possibility of a hedging debacle, which could run the company into bankruptcy. As stated in the terms of divestiture, the corporate tax will be at a fixed rate irrespective of the price of Gold in the international market. This was never the case as the company faced major financial crisis. production. For instance, "in 2011 Anglogold Ashanti produced gold over 380,000 ounces of gold for the year, in 2012 production was a little over 312,000 which showed a decline in over 50,000 ounces of gold" (Ghanaweb, 2019). By virtue of this accountability deficiencies, the veto power enjoyed by government over 
corporate decision making due to its golden share gradually diminished over the years with the sale of majority of its shares.

Secondly, there was also vast retrenchment of workers due to the financial crisis. Under the Stability Agreement, AngloGold was just given two years ultimatum to ensure non-retrenchment of Ghanaian employees. As the two-year expired in 2006, the company is not under any obligation to guarantee workers jobs. Severance package for workers were also obviously absent in the policy agreement. As a result of this, over 6,000 workers of AngloGold were retrenched and most of these left town to other parts of Ghana (Obuasi Today, 2020). These people sold their houses and other property, shut down their businesses and withdrew their wards from some of the most prestigious private schools in town (Obuasi Today, 2020). The result of this was a city that was only a pale shadow of its former glory. The beautifully well-planned company bungalows were left to rot, providing much needed shelter for reptiles (Obuasi Today, 2020).

Thirdly, as part of initiatives taken by government and major shareholders to revamp AngloGold Ashanti, corporate income tax for AngloGold Ashanti is expected to reduce from $35 \%$ to $32.5 \%$. Government is expected to grant the company a tax concession of $\$ 259$ million (Citi News, 2018). The repercussion of this tax waiver is that the government must now find other alternatives to generate revenue to cover up for the tax reduction. Ordinary consumers were usually found at the losing end, with an increase in tax. However, government's injection of capital and the huge debts owned by the company in settling its employees, also raises questions about the capacity of local companies in managing the affairs of the mining industry.

Lastly, it must be said that the credibility of the shareholders of the company were also overlooked. The track record and qualification of bidding companies are crucial in protecting the terms of divestiture within the marketplace. For instance, in August 2008 British charity War on Want published a report accusing Anglo American (who at the time owned $17 \%$ of AngloGold Ashanti) of profiting from the abuse of people in the developing countries in which the company operates (War on Want, 2008) The company disclosed itself in 2006 or in 2008 for unacceptable safety performance in its platinum mines. Additionally, in 2005 the staff of the AGA exploration team in Ituri made an US\$8,000 payment to the FNI, which had been accused of committing various human rights abuses (Kapelus et al. 2009). This further raises questions about the state's ability to effectively provide policy oversight.

\section{Conclusion and Policy Lessons}

The policy implication of Ghana's adherence to privatization as one of the austerity measures under the SAP cannot be underestimated. Ghana's adoption of these measures produced undesirable policy outcome due the complexity of the state-market-society nexus. Despite government's capital investment in the company, it still experienced operational challenges which led to its complete shutdown in 2014. Therefore, some policy lessons can be deduced:

First, there must be strict adherence to local content policy. While the government of Ghana and the management of the company benefited immensely from AngloGold's takeover deal, 
the same cannot be said for the ordinary indigenous employee. Further, about five years into its inception, AngloGold Ashanti faced major operational challenges. The company's takeover by AngloGold of South Africa raises an important question about the ability of MNCs from developing countries to retain ownership and control of relatively successful local companies without getting swallowed by voracious foreign multinationals. Therefore, the government of Ghana must ensure the inclusion and strict enforcement of local content policy in contractual terms with successful bidding private firms. The local content initiative will compel private firms to utilize the countries human and non-human resources. With this, more local people or indigenes will be employed by these private firms. Local manufacturers will generate enough revenue since these private companies will be buying from them. The government must also ensure the severance package for workers in the company. However, employees' contracts were terminated without due acknowledgement to the Labour Act. Section 65 of the Labour Act 2003 explicitly provides for the procedures that must be followed when an employer decides to severe relationship with his/her worker(s). The Sec 65 (1)(a) and (b) state that "When an employer contemplates the introduction of major changes in production, programme, organisation, structure or technology of an under-taking that are likely to entail terminations of employment of workers in the undertaking, the employer shall; (a) provide in writing to the Chief Labour Officer and the trade union concerned, not later than three months before the contemplated changes, all relevant information including the reasons for any termination, the number and categories of workers likely to be affected and the period within which any termination is to be carried out; and (b)consult the trade union concerned on measures to be taken to avert or minimize the termination as well as measures to mitigate the adverse effects of any terminations on the workers concerned such as finding alternative employment" (Labour Act, 2003).

Also, where an employment is closed down or undergoes an amalgamation and that arrangement is likely to sever relationships between a worker and an employer immediately before the close down and this is likely to result in the worker being unemployed or suffering a diminution in the terms and conditions of employment, that worker is entitled to be paid compensation which is known as the redundancy pay (Labour Act, 2003). These packages as most workers complained were non-existent. This is a clarion call on the Ghana labour Commission to be more proactive in enforcing these laws and effectively address such issues brought before it.

Lastly, key accountability measures such as monitoring, and evaluation must be enshrined in the terms of divestiture. Monitoring and evaluation are needed to ensure government performance its policy oversight role effectively. It ensures the compliance of the terms and conditions of the policy directives. This would have helped in evaluating the credibility of bidding companies and provide key performance indicators in assessing the productivity of the company. Sanctions must be duly imposed when there be a breach of contract or policy agreement.

\section{Acknowledgement}

I wish to express my appreciation to Mr. Saaka Sulemana of the Department of Political 
Science, University of Calgary for his assiduous guidance throughout this project. My kind gratitude goes to my parents, Mr. \& Mrs. Danso and my lovely siblings, Mrs. Joyce Danso Asare, Derek Tandoh Danso, and Kelvin Twum Nkansah Danso for their unflinching support. God richly bless you.

\section{References}

Abebrese, J. (2011). Social Protection in Ghana: An overview of existing programmes and their prospects and challenges. Friedrich Ebert Stifting.

Adusei, L. A. (2016). ECG Privatisation: Privatising for who? The experience of Australia, UK. Retrieved from: https://www.modernghana.com/news/721741/ecg-privatisation-privatising-for-who-the-exper ience-of-au.html

AngloGold Ashanti (2004). Completion of Merger of AngloGold Limited and Ashanti Goldfields Limited. Retrieved from: https://www.asx.com.au/asxpdf/20040427/pdf/3lcm4sthtp2jz.pdf

AngloGold Ashanti (2005). 2004 Annual Report: Prepared in Accordnace with IFRS With Condensed Consolidated Financial Accounts Prepared in Accordance with US GAAP. Retrieved from: https://www.sec.gov/Archives/edgar/data/1067428/000120561305000063/annreport.pdf

Appiah-Kubi, K. (2001). State-Owned Enterprises and Privatisation in Ghana. The Journal of Modern African Studies, 39(2), 197-229. https://doi.org/10.1017/S0022278X01003597

Asante, S. K. B. (1987). Privatisation of public enterprises: the case of Ghana, in African Association for Public Administration and Management, ed. Public Enterprises Performance and the Privatisation Debate: a review of the options for Africa. New Delhi.

Atkins, L., \& Wallace, S. (2012). Research Methods in Education: Qualitative research in education. London,: SAGE Publications Ltd. https://doi.org/10.4135/9781473957602

Berg, B. L., \& Howard, L. (2012). Qualitative Research Methods for the Social Sciences. (8th ed). USA: Pearson Educational Inc.

Boafo-Arthur, K. (1999). Ghana: Structural adjustment, democratization, and the politics of continuity. African Studies Review, 42(2), 41-72. https://doi.org/10.2307/525364

Bryman, A., \& Bell, E. (2011). Business research methods. Cambridge. New York, NY: Oxford University Press.

Creswell, J. W. (2009). Research Design: Qualitative, Quantitative and Mixed Methods Approaches (3rd ed.). Los Angeles: Sage.

Citi News (2018, June 21). Minority questions \$259m tax waiver for AngloGold. Retrieved from:

https://citinewsroom.com/2018/06/21/minority-questions-259m-tax-waiver-for-anglogold/ 
Danso, A. (1992). Privatization of State-Owned Enterprises in Africa: The Case of Ghana. South Eastern Political Review, 335-351. https://doi.org/10.1111/j.1747-1346.1992.tb00314.x

Danso, E. (2019). Anatomy of the Privatization of State-Owned Enterprises in Ghana: Implication for Policy and Accountability. Journal of Public Administration and Governance, 9(4), 181-199. https://doi.org/10.5296/jpag.v9i4.15600

Divestiture Implementation Committee (DIC). (1999). Divestiture of State-Owned Enterprises in Ghana. Accra: DIC.

Frempong, A. K. D. (2017). Electoral politics in Ghana's Fourth Republic. Accra: Yamens Press Limited.

Ghana Labour Act (2003). Act 651. Retrieved from: https://www.ihrmp.com/wp-content/uploads/2019/12/Labour-Act-2003-Act-651.pdf

GhanaWeb (2003, August 5). Proposed Merger of Anglogold Limited and Ashanti Goldfields Company Limited. Retrieved from: https://www.ghanaweb.com/GhanaHomePage/NewsArchive/Proposed-Merger-Of-Anglogold -Limited-and-Ashanti-Goldfields-Company-Limited-40546

GhanaWeb (2019, January 23). Cheap politics cause of partial shutdown of Anglogold Ashanti - Former Obuasi MCE. Retrieved from: https://www.ghanaweb.com/GhanaHomePage/NewsArchive/Cheap-politics-cause-of-partialshutdown-of-Anglogold-Ashanti-Former-Obuasi-MCE-717599

Gyimah-Boadi, E. (1990). Economic Recovery and Politics in PNDC's Ghana. Journal of $\begin{array}{llll}\text { Commonwealth and } \quad \text { Comparative } & \text { 328-43. }\end{array}$ https://doi.org/10.1080/14662049008447595

Gyimah-Boadi, E. (1991). State Enterprises Divestiture: Recent Ghanaian Experiences, in D. Rothchild, ed., Ghana: the political economy of recovery. Boulder, CO: Lynne Rienner.

Hale, G. E. (2018). Uneasy Partnership: The Politics of Business and Government in Canada. North York, Ontario. University of Toronto Press.

Hamid, I. S. A. (2016). Comparing How Ghana and Canada Succeeded in the adoption of the National Health Insurance (NHI): A Multiple Streams Approach. Journal of Public Administration and Governance, 6(2), 150-165. https://doi.org/10.5296/jpag.v6i2.9529

Handley, A. (2007). Business, Government, and the Privatisation of the Ashanti Goldfields Company in Ghana. Canadian Journal of African Studies, 41 (1) Retrieved from: Canadian Business \& Current Affairs Database. https://doi.org/10.1080/00083968.2007.10751350

Haruna, P, F. (2003). Reforming Ghana's Public Service: Issues and Experiences in Comparative Perspective. Public Administration Review, 63(3), 343-354. https://doi.org/10.1111/1540-6210.00294

Kapelus P., Hamann, R., O'Keefe, E. (2009). Doing business with integrity: the experience of AngloGold Ashanti in the Democratic Republic of Congo. Int. Soc. Sci, 57, 119-30. 
https://doi.org/10.1111/j.1468-2451.2009.00711.x

Kikeri, S., \& Nellis, J. (2004). An Assessment of Privatization. World Bank Research Observer, 19 (1): 87-118. https://doi.org/10.1093/wbro/lkh014

Kothari, R. C. (2004). Research Methodology: Methods \& Techniques. New Delhi: New Age International $(\mathrm{P})$ Ltd.

MarketWatch (2003, August 5). AngloGold, Ashanti agree on merger plan. Retrieved from: https://www.marketwatch.com/story/anglogold-shares-rise-on-merger-news-gold-steadies

Nellis, J.R. (1986). Public Enterprises in Sub-Saharan Africa. World Bank Washington, DC.

Nellis, J.R. (2008). Privatization in Africa. What Has Happened? What Is to Be Done? In G. Roland, Privatization: Successes and Failures, (pp. 109-135). New York: Columbia University Press. https://doi.org/10.7312/rola14160-006

Nikoi, E. (2015). Ghana's Economic Recovery Programme and the Globalisation of Ashanti Goldfields Company Ltd. Journal of International Development. https://doi.org/10.1002/jid.3199

Obadan, M. I. (2009). Economic and Social Impact of Privatisation of State-owned Enterprises in Africa. Oxford: African Books Collective. Retrieved from: Project MUSE database.

Obuasi Today (2020, April 21). Return of AngloGold Ashanti: Will Obuasi Rise Again? Retrieved from: https://obuasitoday.com/return-of-anglogold-ashanti-will-obuasi-rise-again/

Osei, R. D. (2011). Reducing Poverty through a Social Grant Programme: The Case of Ghana. Institute of Social Science and Economic Research, Accra.

Osuala, E. (2007). Introduction to Research Methodology. Nigeria: Africana- First Publishers.

Potter, A. (2015). Privatisation in Ghana: Successes During Economic Collapse and Authoritarianism. African Affairs, 90 (361), 523-536.

Tewksbury, R. (2009). Qualitative versus Quantitative Methods: Understanding Why Qualitative Methods are Superior for Criminology and Criminal Justice. Journal of Theoretical and Philosophical Criminology.

Tangri, R. (1991). The Politics of State Divestiture in Ghana. African Affairs, 90(361), 523-536. https://doi.org/10.1093/oxfordjournals.afraf.a098467

Tweneboa, F. D. (1999). Privatisation of a Large State Corporation - Some Issues Arising. Paper Presented at a Workshop on Privatisation and Infrastructure Development, Accra: GIMPA.

War on Want (2008). Mines Firm Profit from Abuse of Poor. Retrieved from: https://www.waronwant.org/media/mines-firm-profits-abuse-poor. 


\section{Copyright Disclaimer}

Copyright for this article is retained by the author(s), with first publication rights granted to the journal.

This is an open-access article distributed under the terms and conditions of the Creative Commons Attribution license (http://creativecommons.org/licenses/by/4.0/). 